\title{
Posture defects and the speed of the centre of foot pressure in children of school age
}

\section{Wady postawy a prędkość środka nacisku stóp u dzieci w wieku szkolnym}

\author{
Jacek Wilczyński, Magdalena Lipińska-Stańczak, Katarzyna Szaraniec
}

Department of Neurology, Neurological Rehabilitation and Kinesitherapy, Institute of Physiotherapy, Faculty of Health Sciences, Jan Kochanowski University, Kielce, Poland

Head of Department: Prof. Jacek Wilczyński MD, PhD

Key words: posture defects, the centre of foot pressure, lateral speed, anteroposterior speed.

Słowa kluczowe: wady postawy, środek nacisku stóp, prędkość boczna, prędkość przednio-tylna.

\begin{abstract}
Introduction: The development of civilisation and the modern lifestyle of children and teenagers have caused an increase in the number of cases of faulty body posture.

Aim of the research: To analyse the relationship between posture defects and the speed of the centre of foot pressure in school-age children.

Material and methods: The research included 503 girls and boys aged 12-15 years. The research approach used a spatial photogrammetry technique. Lateral speed and anteroposterior speed of the centre of foot pressure were tested on a Cosmogamma platform.

Results: Lateral speed ranged from $8.22 \mathrm{~mm} / \mathrm{s}$ with eyes open to $7.63 \mathrm{~mm} / \mathrm{s}$ with eyes closed. In correct posture, from 8.45 $\mathrm{mm} / \mathrm{s}$ with eyes open to $7.64 \mathrm{~mm} / \mathrm{s}$ with eyes closed. In the defective posture, from $7.90 \mathrm{~mm} / \mathrm{s}$ with eyes open to $7.63 \mathrm{~mm} / \mathrm{s}$ with eyes closed. Antero-posterior speed varied from $10.50 \mathrm{~mm} / \mathrm{s}$ with eyes open to $10.56 \mathrm{~mm} / \mathrm{s}$ with eyes closed. In the correct posture, from $10.73 \mathrm{~mm} / \mathrm{s}$ with eyes open to $10.64 \mathrm{~mm} / \mathrm{s}$ with eyes closed. In the defective posture, from $10.17 \mathrm{~mm} / \mathrm{s}$ with eyes open to $10.45 \mathrm{~mm} / \mathrm{s}$ with eyes closed.

Conclusions: Analysis of variance of lateral speed showed a significant effect only of test options $(p<0.002)$. Lateral speed in the test with eyes closed significantly decreased both in the correct and defective posture. There were no significant differences, however, in lateral speed between the correct and incorrect posture. Analysis of variance did not show any significant effects for anteroposterior speed.
\end{abstract}

\section{Streszczenie}

Wprowadzenie: Rozwój cywilizacji oraz współczesny styl życia dzieci i młodzieży powoduje ustawiczne zwiększanie się częstości występowania wad postawy.

Cel pracy: Analiza związku między wadami postawy a prędkością środka nacisku stóp u dzieci w wieku szkolnym.

Materiał i metody: Badaniami objęto 503 dziewcząt i chłopców w wieku 12-15 lat. W badaniach postawy zastosowano technikę fotogrametrii przestrzennej. Prędkość boczną i prędkość przednio-tylną środka nacisku stóp badano na platformie Cosmogamma.

Wyniki: Prędkość boczna oscylowała od $8,22 \mathrm{~mm} / \mathrm{s}$ przy oczach otwartych do 7,63 mm/s przy oczach zamkniętych; w postawie prawidłowej od $8,45 \mathrm{~mm} / \mathrm{s}$ przy oczach otwartych do 7,64 mm/s przy oczach zamkniętych, a w postawie wadliwej od $7,90 \mathrm{~mm} / \mathrm{s}$ przy oczach otwartych do 7,63 mm/s przy oczach zamkniętych. Prędkość przednio-tylna oscylowała od 10,50 mm/s przy oczach otwartych do $10,56 \mathrm{~mm} / \mathrm{s}$ przy oczach zamkniętych; w postawie prawidłowej od $10,73 \mathrm{~mm} / \mathrm{s} \mathrm{przy} \mathrm{oczach} \mathrm{otwar-}$ tych do 10,64 mm/s przy oczach zamkniętych, a w postawie wadliwej od 10,17 mm/s przy oczach otwartych do 10,45 $\mathrm{mm} / \mathrm{s}$ przy oczach zamkniętych.

Wnioski: Analiza wariancji prędkości bocznej wykazała jedynie istotny efekt opcji badania $(p=0,002)$. Prędkość boczna w teście przy oczach zamkniętych istotnie się zmniejszyła zarówno w postawie prawidłowej, jak i wadliwej. Nie wystąpiły jednak istotne różnice prędkości bocznej między postawą prawidłową i wadliwą. Analiza wariancji nie wykazała istotnych efektów dla prędkości przednio-tylnej. 


\section{Introduction}

The development of civilisation and the modern lifestyle of children and teenagers have caused an increase in the number of cases of faulty body posture. The results of attempts to correct body posture are still unsatisfactory. They are an inspiration to verify the programs used and to look for new methods of therapy. Among all body postures the treatment of lateral curvatures of the spine is a long-lasting process, which often continues until adulthood. This defect determines the choice of future career and a kind of performed work. That is why preventive treatment, screening examination, and posture re-education are necessary. The human body is not a rigid Newtonian solid. Maintaining an upright posture is a kind of act of mobility, the ability of coordination, and the development of that coordination is a long-term process, requiring a large number of repetitions. Body posture is a way of keeping a person in a relaxed standing position, of which the external manifestations are a spatial arrangement of each segment of the body and the silhouette of the body. Posture as a way of keeping oneself is not a passive system of the body segments, but belongs to motor acts with a high degree of automation. As a way of keeping oneself, the body posture must be seen as a dynamic act, maintaining an adequate body system in spite of the force of gravity and in the conditions of unstable equilibrium [1-4]. Balance is a certain state of the postural system. This condition is characterised by vertical orientation of the body achieved by balancing the forces working on the body and their moments. Balance is provided by the nervous system by reflexive tension of relevant muscle groups called postural or anti-gravitational muscles. Because the chaotic movements of the centre of gravity are two-dimensional, additional information on the stability of the posture can be obtained by analysing the individual components of the route of statokinesiogram, i.e. separate sway in the sagittal plane and in the frontal plane [5-13].

\section{Aim of the research}

The aim of the study was to analyse the relationship between body posture in the sagittal plane and the speed of the centre of foot pressure in school-age children, tested by Romberg test.

\section{Material and methods}

The research included 503 girls and boys aged 12-15 years from randomly selected Primary School No 13 and Secondary School No 4, in Starachowice. The study group consisted of 247 (49.11\%) girls and 256 (50.89\%) boys. Of these, 60 were 12-year-old girls (24.29\%), 60 were 13-year-old girls (24.29\%), 65 were 14 -year-old girls (26.32\%), and 62 were 15 -yearold girls (25.10\%). Sixty-five were 12-year-old boys
(25.39), 61 were 13-year-old boys (23.83\%), 60 were 14 -year-old boys (23.44\%), and 70 were and 15 -yearold boys (27.34\%). The size distributions of age and sex groups did not differ significantly. The study was performed in November and December 2005. To study body posture a spatial photogrammetry technique was used based on the effect of projection moiré (Figure 1) [14, 15]. The lateral speed and anteroposterior speed of the centre of foot pressure were tested on Cosmogamma platform using an Emildue R50300. The test was carried out for the standard evaluation of stability in a relaxed standing position (Romberg test) consisting of two successive trials lasting $30 \mathrm{~s}$ each: first with eyes open (OE - open eyes) and second with eyes closed (CE - closed eyes) (Figure 2) [16]. The lower the value of the parameters, the more accurate the process of posture control.

\section{Statistical analysis}

For statistical analysis the following were used: the arithmetic mean $(x)$, the standard deviation (s), Kruskal-Wallis's analysis of variance, Kolmogorov-Smirnov test, and for post hoc analysis - the Bonferroni test [17].

\section{Results}

Analysis of variance showed a significant difference in the body height in relation to sex $(p \leq 0.001)$, a significant difference in terms of age $(p \leq 0.001)$, and significant interaction of the age and gender on the height of the tested $(p \leq 0.001)$. In the test group there was a significant difference in body mass in relation to gender $(p \leq 0.03)$, a significant difference in terms of age ( $p \leq 0.001)$, and significant interaction of gender and the age on body mass of the tested children $(p \leq 0.001)$. There was a significant variation in body mass index (BMI) in relation to age ( $p \leq 0.004)$. No significant difference was observed in relation to gender. There was no significant interaction of gender and age on BMI. The body postures of the tested were divided into correct $\left(\mathrm{K}_{1}, \mathrm{R}_{2}, \mathrm{~L}_{1}\right.$ types) and defective groups based on a modification of Wolański typology. Defective postures included $\mathrm{K}_{2}, \mathrm{~L}_{2}$, and $\mathrm{R}_{1} \mathrm{P}$ types, i.e. round, concave, and flat back [4]. Two hundred and ninety-seven $(59.05 \%)$ correct postures were observed and 206 (40,95\%) were defective. The lateral speed of the tested varied from $8.22 \mathrm{~mm} / \mathrm{s}$ with $\mathrm{OE}$ to $7.63 \mathrm{~mm} / \mathrm{s}$ with CE. The difference in Romberg test was 0.59 . Variations in the correct posture were from $8.45 \mathrm{~mm} / \mathrm{s}$ with OE to $7.64 \mathrm{~mm} / \mathrm{s}$ with CE. The difference in Romberg test was 0.82 . Variations in the defective posture were from $7.90 \mathrm{~mm} / \mathrm{s}$ with $\mathrm{OE}$ to 7.63 $\mathrm{mm} / \mathrm{s}$ with CE. The difference in Romberg test was 0.27 (Table 1, Figure 3). Antero-posterior speed varied from $10.50 \mathrm{~mm} / \mathrm{s}$ with OE to $10.56 \mathrm{~mm} / \mathrm{s}$ with CE. The difference in Romberg test was 0.06 . Variations in the correct posture were from $10.73 \mathrm{~mm} / \mathrm{s}$ with $\mathrm{OE}$ 


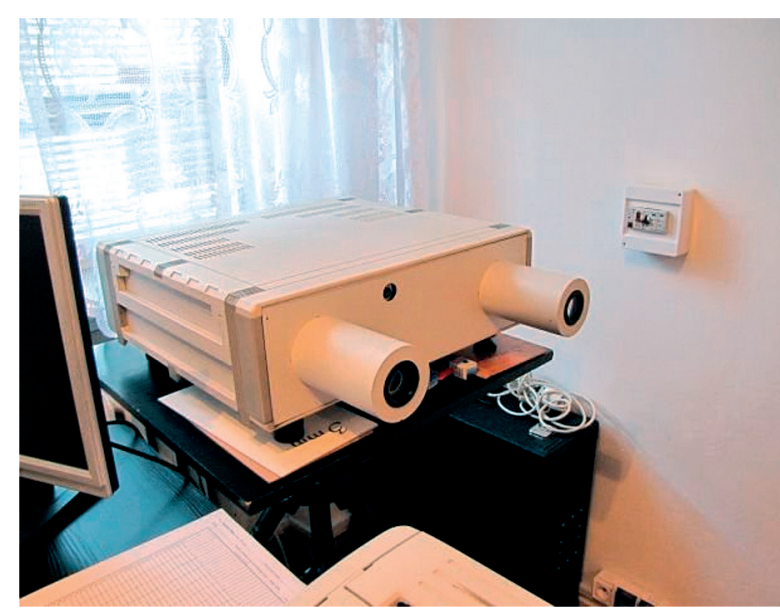

Figure 1. The apparatus for the test by moiré method [15]

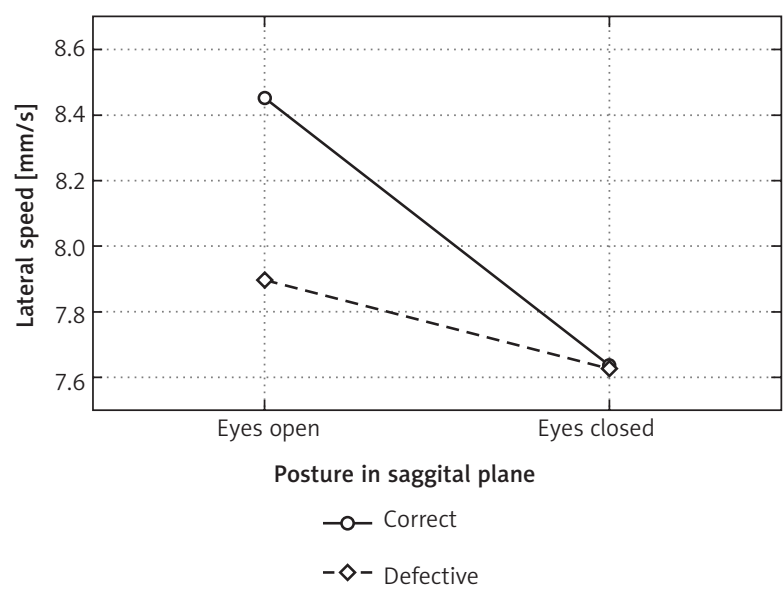

Figure 3. Lateral speed

to $10.64 \mathrm{~mm} / \mathrm{s}$ with CE. The difference in Romberg test was 0.09 . Variations in the incorrect posture were from $10.17 \mathrm{~mm} / \mathrm{s}$ with OE to $10.45 \mathrm{~mm} / \mathrm{s}$ with CE. The difference in Romberg test was 0.28 (Table 2, Figure 4).

\section{Discussion}

My own research proves the fact that there are a large number of children and teenagers with faulty body postures. These are predominantly cases of lateral curvature of the spine $(52 \%)$, followed by scoliosis (47\%), then concave backs (20\%), flat backs (20\%), and round backs $(0.80 \%)$ [18]. Body balance is ensured by integration in nervous system of peripheral control, ascending, conventionally known as ankle-head steering and descending head-ankle. Just these two types of control ensure a stable upright posture during relaxed standing and during locomotion. Both controls are complementary, so the failure of one of them may be compensated by the activity of the other. Consequently, in a complex system responsible for the control of posture two distinct but interdepen-

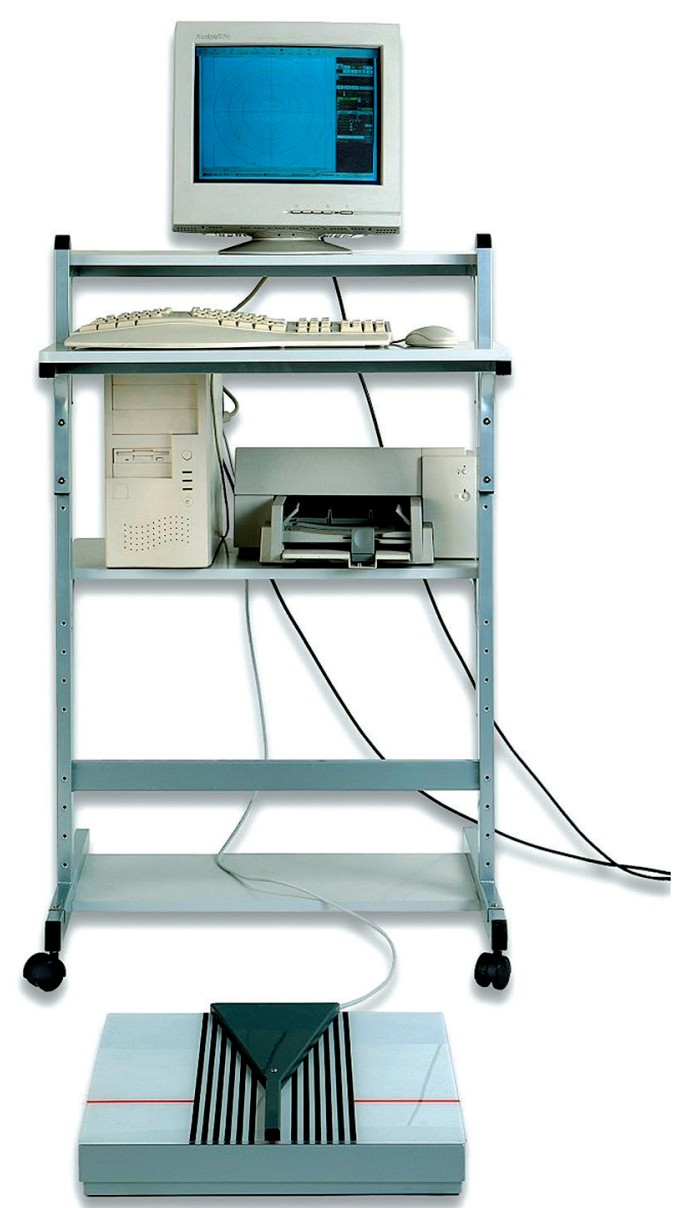

Figure 2. The Cosmogamma platform, Emildue R50300 [16]

dent systems can be distinguished. The first is the system-stabilising look, which consists of control of the direction of visual acuity during movements of the head and the whole body. The second is the system stabiliing posture, which keeps the body in balance at rest and in motion. Both systems, the stabilising look and stabilising posture, differ in their source of receptor information, information about the motor reactions of the various parts of the body, and the involvement of different motion pathways in central nervous system. They are closely interdependent because the stabilisation of looks is not possible until the body and head with the eyeballs are also not stable. However, the correct vision, which depends on the stable look, is one of the main senses enabling control and stabilisation of the posture. Among the unconditioned reflexes with which a child is born, an important place is occupied by reactions known as posture reflexes. The latter are numerous and include three groups: static, setting, and balance reactions, with many subgroups. All these reactions are connected and in essence provide the stability of the adopted posture (static reactions), allow the adoption of proper posture after im- 
Table 1. Lateral speed

\begin{tabular}{|c|c|c|c|c|c|c|c|}
\hline \multirow[t]{3}{*}{ Independent variables } & \multicolumn{6}{|c|}{ Lateral speed [mm/s] } & \multirow{3}{*}{$\begin{array}{c}\text { Difference } \\
\text { (OE-CE) }\end{array}$} \\
\hline & \multicolumn{3}{|c|}{$\mathrm{OE}$} & \multicolumn{3}{|c|}{ CE } & \\
\hline & $x$ & $n$ & $s$ & $x$ & $n$ & $s$ & \\
\hline Correct posture & 8.45 & 297 & 4.00 & 7.64 & 297 & 3.08 & 0.82 \\
\hline Defective posture & 7.90 & 206 & 3.52 & 7.63 & 206 & 2.91 & 0.27 \\
\hline Total & 8.22 & 503 & 3.82 & 7.63 & 503 & 3.01 & 0.59 \\
\hline
\end{tabular}

Table 2. Anteroposterior speed

\begin{tabular}{|c|c|c|c|c|c|c|c|}
\hline \multirow[t]{3}{*}{ Independent variables } & \multicolumn{6}{|c|}{ Anteroposterior speed [mm/s] } & \multirow{3}{*}{$\begin{array}{c}\text { Difference } \\
\text { (OE-CE) }\end{array}$} \\
\hline & \multicolumn{3}{|c|}{$\mathrm{OE}$} & \multicolumn{3}{|c|}{ CE } & \\
\hline & $x$ & $n$ & $s$ & $x$ & $n$ & $s$ & \\
\hline Correct posture & 10.73 & 297 & 3.62 & 10.64 & 297 & 3.87 & 0.09 \\
\hline Defective posture & 10.17 & 206 & 3.59 & 10.45 & 206 & 3.82 & -0.28 \\
\hline Total & 10.50 & 503 & 3.62 & 10.56 & 503 & 3.84 & -0.06 \\
\hline
\end{tabular}

proper position (setting and straightening reflexes), and ensure the balance of the body upon changes of position of the centre of gravity (balance reflexes). These reflexes are somehow built into the mechanism of regulation of body posture. However, earlier in the course of development, the conditioned reflexes are formed, based on unconditioned reflexes, which in turn form a chain of reflexively conditioned actions called dynamic stereotype. Further repetition of stimuli and responses leads in turn to the production of motion habits, and those, in turn, form the basis of the automation of motor actions [5, 18]. The development of sensory organisation for balance control in children is still unclear. Steindl, Kunz, Schrott-Fischer, and Scholtz studied the effects of age and gender on maturation of sensory systems and balance control in relation to gender and age. They studied a total of 128 children aged from 3 to 16 years and 23 adults using the Sensory Organisation Test (Test Equi). Age-related changes during the test procedure showed a development tendency of the sensory process. The influence of proprioceptive information on balance seemed to be completely developed between 3 and 4 years of age. Visual and vestibular information reached the level of adults between 15 and 16 years of age. Significant differences between girls and boys were also shown. Age-related assessment of sensory organisation for balance control (posture-defect mechanisms can be used for differentiation between physiological and pathological results in balance control) can be used for monitoring therapy progress of hyperactivity or learning disability [19]. Analysis of variance with the double classification showed a significant effect of test options $(p \leq 0.002)$. Lateral speed in the test with CE significantly decreased in both the correct and defec-

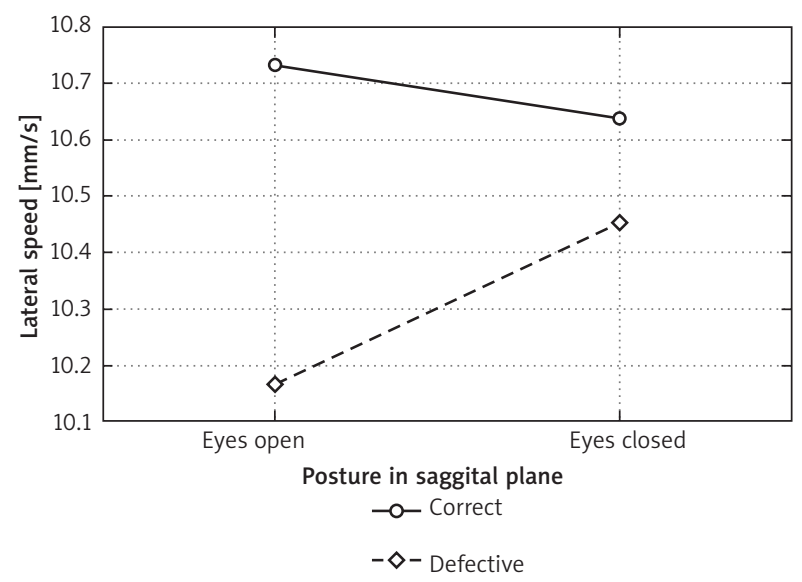

Figure 4. Anteroposterior speed

tive postures (Table 3). Post-hoc analysis (Bonferoni test) confirmed this effect. In the test with $\mathrm{CE}$ the value of the lateral speed significantly decreased in both the correct and defective postures (Table 4). Since the parameters of the lateral speed in the test with CE do not deteriorate we are dealing with a lack of skills in the use of vision in the process of maintaining body balance among younger children. There is a lack of adequate coordination between vision and the motor system, which in children is in the process of ongoing development. However, there were no significant differences laterally between the correct and incorrect posture. Analysis of variance with double classification did not show any significant effects for anteroposterior speed. There were no significant differences in anteroposterior speed between the correct and incorrect posture (Table 5). Posture defects observed in the population of children aged 12-15 years did not 
Table 3. Analysis of variance with double classification for lateral speed

\begin{tabular}{|lcccccc|}
\hline Independent variables & $\begin{array}{c}\text { DF } \\
\text { effect }\end{array}$ & $\begin{array}{c}\text { MS } \\
\text { effect }\end{array}$ & DF error & MS error & $F$ & Value of $p$ \\
Posture & 1 & 19.48 & 501 & 15.614 & 1.24 & 0.26 \\
Test option & 1 & 71.62 & 501 & 7.97 & 8.98 & 0.002 \\
Interaction & 1 & 18.04 & 501 & 7.97 & 2.26 & 0.133 \\
\hline
\end{tabular}

$D F$ - degree of freedom, MS - mean square, $F$-relation of MS effect to MS error, $p$-level of significance

Table 4. Post hoc analysis (Bonferroni test) for lateral speed

\begin{tabular}{|lccccc|}
\hline Independent variables & Test options & $(1)$ & $(2)$ & $(3)$ & (4) \\
Correct posture & LS (OE) & $\mathbf{8 . 4 5}$ & $\mathbf{7 . 6 3}$ & $\mathbf{7 . 8 9}$ & $\mathbf{7 . 6 2}$ \\
Correct posture & LS (CE) & 0.003 & 0.003 & 0.730 & 0.049 \\
Defective posture & LS (OE) & 0.730 & 1.000 & 1.000 & 1.000 \\
Defective posture & LS (CE) & 0.050 & 1.000 & 1.000 & 1.000 \\
\hline
\end{tabular}

Table 5. Analysis of variance with double classification for anteroposterior speed

\begin{tabular}{|lcccccc|}
\hline Independent variables & DF effect & MS effect & DF error & MS error & $F$ & Value of $p$ \\
Posture & 1 & 33.82 & 501 & 20.47 & 1.65 & 0.19 \\
Test option & 1 & 2.17 & 501 & 7.34 & 0.29 & 0.58 \\
Interaction & 1 & 8.66 & 501 & 7.34 & 1.17 & 0.27 \\
\hline
\end{tabular}

affect the speed of COP in the assessment carried out on the Cosmogamma balance platform. Lateral speed differences with eyes open and closed may be a measure of maturation assessment of the visual inspection of balance in 12-15-year-old children. Therefore, the problem of relations between body posture in the sagittal plane and the speed of the centre of the foot pressure requires further research and analysis.

\section{Conclusions}

Analysis of variance with double classification of lateral speed showed a significant effect of the test option. Lateral speed in the test with CE significantly decreased in both the correct and defective posture. Post-hoc analysis (Bonferoni test) confirmed this effect. There were no significant differences in lateral speed between the correct and incorrect posture. Analysis of variance with the double classification did not show any significant effects for anteroposterior speed. There were no significant differences in anteroposterior speed between the correct and incorrect posture. Posture defects observed in the population of children aged 12-15 years did not affect the speed of $\mathrm{COP}$ in the assessment carried out on the Cosmogamma balance platform. Lateral speed differences with eyes open and closed may be a measure of maturation assessment of the visual inspection of balance in 12-15-year-old children. The problem of relations between body posture in the sagittal plane and the speed of the centre of foot pressure requires further research.

\section{References}

1. Nowotny J, Nowotny-Czupryna O, Czupryna K. Reedukacja posturalna $\mathrm{w}$ systemie stacyjnym [Polish]. AWF, Katowice 2008.

2. Magnus O. Rudolf Magnus. Physiologist and Pharmacologist. Springer Verlag, Berlin 2002.

3. Wilczyński J. Posturologia - nauka o postawie ciała człowieka [Polish]. Studia Medyczne 2011; 27: 7-17.

4. Wolański N. Wyprostowana postawa stojąca [Polish]. Wychowanie Fizyczne i Zdrowotne 2012; 4: 9-28.

5. Błaszczyk JW. Biomechanika kliniczna. Podręcznik dla studentów medycyny i fizjoterapii [Polish]. PZWL, Warszawa 2004.

6. Beaulieu M, Allard P, Simoneau M, et al. Relationship between oscillations about the vertical axis and center of pressure displacements in single and double leg upright stance. Am J Phys Med Rehabil 2010; 89: 809-16.

7. Bruyneel AV, Chavet P, Bollini G, et al. Idiopathic scoliosis and balance organisation in seated position on a seesaw. Eur Spine J 2010; 19: 739-46.

8. Eshraghi E, Maroufi N, Sanjari M, et al. Static dynamic balance of schoolgirls with hyperkyphosis. Scolisis 2009; 4: 5.

9. Lee RS, Reed DW, Saifuddin A. The correlation between coronal balance and neuroaxial abnormalities detected on MRI in adolescent idiopathic scoliosis. Eur Spine J 2012; 21: 1106-10. 
10. Liao K, Walker MF, Joshi AC, et al. The linear vestibuloocular reflex, locomotion and falls in neurological disorders. Restor Neurol Neurosci 2010; 28: 91-103.

11. Ocetkiewicz T, Skalska A, Grodzicki T. Badanie równowagi przy użyciu platformy balansowej ocena powtarzalności metody [Polish]. Gerontol Pol 2006; 14: 144-8.

12. Shi L, Wang D, Chu WC, et. al. Automatic MRI segmentation and morphoanatomy analysis of the vestibular system in adolescent idiopathic scoliosis. Neuroimage 2011; 54: $180-8$.

13. Tao F, Wang Z, Li M, et al. A comparison of anterior and posterior instrumentation for restoring and retaining sagittal balance in patients with idiopathic adolescent scoliosis. J Spinal Disord Tech 2012; 25: 303-8.

14. Nowotny J, Podlasiak P, Zawieska D. System analizy wad postawy [Polish]. PWN, Warszawa 2003.

15. www.mogkik.pl

16. www.Technomex.pl

17. Komputerowy program statystyczny: Statistica.7.1 statsoft, 2007.

18. Wilczyński J. Body posture in the sagittal plane and the path length among girls and boys at school age. Studia Medyczne 2014; 30: 14-20.

19. Steindl R, Kunz K, Schrott-Fischer A, Scholtz AW. Effect of age and sex on maturation of sensory systems and balance control. Dev Med Child Neurol 2006; 48: 477-82.

\section{Address for correspondence:}

Prof. Jacek Wilczyński MD, PhD

Department of Neurology

Neurological Rehabilitation and Kinesitherapy

Institute of Physiotherapy

Faculty of Health Sciences

Jan Kochanowski University

ul. Żeromskiego 5, 25-369 Kielce, Poland

Phone: +48 603703926

E-mail: jwilczynski@onet.pl 